\title{
Never forget basics
}

\author{
M V S Satya Prakash, Suman Lata, Ashok Shankar Rao Badhe
}

Department of Anaesthesiology and Critical Care, JPPMER, Puducherry, Puducherry, India

\section{Correspondence to}

Dr M V S Satya Prakash, munaganuri1975@yahoo.co.in

Accepted 4 November 2016

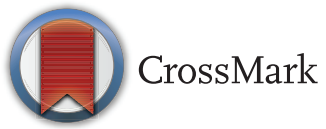

To cite: Satya Prakash MVS, Lata S, Badhe ASR. BMJ Case Rep Published online: [please include Day Month Year] doi:10.1136/bcr-2016218340

\section{DESCRIPTION}

A patient with open fracture of both bones of a leg was posted for wound debridement and external fixation. L3-L4 space was identified by the loss of resistance technique with Tuohy's needle. An epidural catheter was passed through the Tuohy's needle. Aspiration of epidural catheter resulted in cerebro spinal fluid (CSF) tap. We tried to pull the catheter while the needle was in situ. Although there was a little resistance, we could remove the catheter. When we inspected the catheter, it was found that epidural catheter tip with only the $8 \mathrm{~cm}$ mark was visible (figure 1). Immediately the Tuohy's needle was removed and it was concluded that the epidural catheter tip was neither palpable nor visible. The patient was given general anaesthesia and allowed surgeons to proceed with the planned surgery. We decided to document and explain to the patient about sheared catheter and not to retrieve the retained epidural catheter by

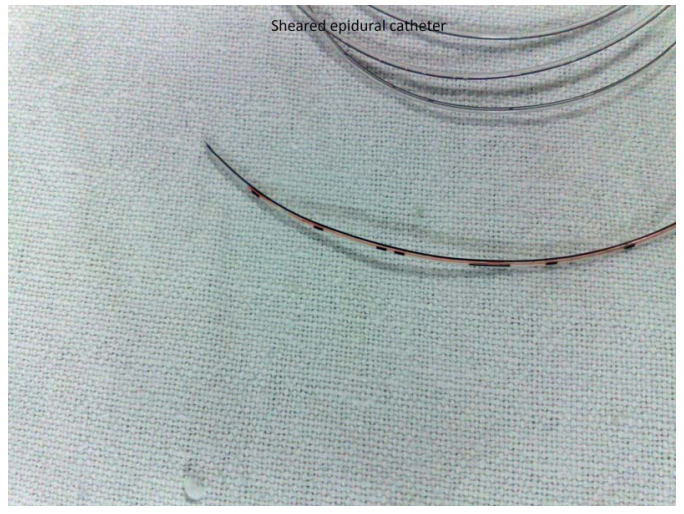

Figure 1 Sheared epidural catheter. operation until symptoms develop. After the surgery, X-ray of the lumbar spine did not show the presence of the sheared epidural catheter. We decided to perform a CT scan if patient reports symptoms. The patient was discharged after 1 month and followed up for 1 year. No complications or symptoms were detected. Shearing of the epidural catheter may be either due to wrong technique (pulling the catheter while the needle is in situ) or an old catheter was used (the epidural catheter was manufactured 4 years ago). The decision not to retrieve the catheter was taken according to the guidelines proposed by Deepanjali Pant et al. ${ }^{12}$

\section{Learning points}

Every procedure is bound to have complications. But complications can be minimised by following proper guidelines.

- We should never forget basics.

Contributors MVSSP had identified the problem. SL and ASRB had helped in managing the complication. MVSSP had written the report.

Competing interests None declared.

Patient consent Obtained.

Provenance and peer review Not commissioned; externally pee reviewed.

\section{REFERENCES}

1 Deepanjali Pant, Pradeep Jain, Pravesh Kanthed, et al. Epidural catheter breakage: a dilemma. Indian J Anaesth 2007;51:434-7.

2 DeVera HV, Ries M. Complication of continuous spinal microcatheters: should we seek their removal if sheared? Anesthesiology 1991;74:794.

Copyright 2016 BMJ Publishing Group. All rights reserved. For permission to reuse any of this content visit http://group.bmj.com/group/rights-licensing/permissions.

BMJ Case Report Fellows may re-use this article for personal use and teaching without any further permission.

Become a Fellow of BMJ Case Reports today and you can:

- Submit as many cases as you like

- Enjoy fast sympathetic peer review and rapid publication of accepted articles

- Access all the published articles

- Re-use any of the published material for personal use and teaching without further permission

For information on Institutional Fellowships contact consortiasales@bmjgroup.com

Visit casereports.bmj.com for more articles like this and to become a Fellow 